\title{
THE IMPACT OF THE FERTILIZATION SYSTEM ON FERTILITY OF DRAINED SOD-PODSOLIC SOIL IN A SHORT-TERM CROP ROTATION
}

\author{
O. I. Savchuk, Ph.D of Agriculture, Senior Research Fellow, \\ E-mail: grunt17isgp@gmail.com
}

A. O. Melnychuk, Ph.D of Agriculture, Senior Research Fellow, E-mail: andriy_melnychuk@ukr.net

Institute for Agriculture of Polissia NAAS,

O. V. Drebot, Ph.D of Agriculture, Associate Professor, E-mail: o_drebot@ukr.net,

A. P. Kudryk, Ph.D of Agriculture, Associate Professor,

E-mail:zem_kudryk@ukr.net,

O. V. Zubova, assistant teacher,

E-mail: olenazuboval@gmail.com

Zhytomyr National Agroecological University

\section{ABSTRACT}

The relevance of research is connected with the effective use of drained land in the face of climate change. Goal. To determine the optimum fertilizer system and to study its effectiveness on the fertility of sod-podzolic soil in short-term rotation: soybean - winter wheat - sunflower - buckwheat. Methods. Research was conducted in the field and performed within the framework of the three-year experiment. Yield was calculated by weighing method. The humus balance in the soil was performed according to the method of Lykov (1976). Results. During the vegetation periods of 2016-2019, the sunflower was the least responsive to the soil-air drought, which, on the recommended standard $\mathrm{N}_{60} \mathrm{P}_{60} \mathrm{~K}_{90}$ background, combined with $40 \mathrm{t} / \mathrm{ha}$ of manure and the increased rate $\mathrm{N}_{90} \mathrm{P}_{90} \mathrm{~K}_{135}$ and 4.0 tonnes of precursor by-products provided seed yield levels 2.3 and 2.4 t/ha respectively. The maximum harvest produce from 1 ha of crop rotation area is marked on a raised background $\left(\mathrm{N}_{62} \mathrm{P}_{84} \mathrm{~K}_{96}+3.3\right.$ tonnes of by-products) -3.20 tonnes of grain units. Conclusions. An alternative fertilizer system (replacement of 10 tons of manure per 1 ha of arable land by 3.3 tons of byproducts on the mineral fertilizers background) provided a positive balance of nutrients and humus in short-term rotation. Prospects. Further scientific studies expect to reduce the amount of phosphorus and potassium fertilizers that provided by the by-products plowing of all crops in rotation. 
Keywords: drained soils, productivity, soil fertility.

\section{INTRODUCTION}

Polissia zone is characterized by the predominance of sod-podzolic gley soils. Most of them are drained. Poor work of drained reclamation systems and climate changes allow to grow market crops which are not typical for this region (Savchuk et al., 2018). Therefore, the significance of the given research is in the development of an optimum crop fertilizer system in order to preserve the fertility of the drained soil.

Analysis of recent research and publications. A large number of scientists in all countries are studying the effects of different fertilizing systems on soil and crop yield. Both doses of fertilizers and their combining or mix are investigated. The positive result of the combination of mineral and organic fertilizers is proved (Chen Lin et al., 2020; Guo et al., 2020; Chen Jen-Hshuan, 2006; Shah, Mohammad \& Shafi, 2015). Some studies show the effective use of mineral fertilizers in the amount of $\mathrm{N}_{60} \mathrm{P}_{60} \mathrm{~K}_{60}$ in combination with manure, which increased the productivity of winter wheat by $19-23 \%$ (Pashkova, 2019). It is also proved that application of unbalanced composition of mineral fertilizers reduces the efficiency of their use in several times and limits the impact of fertilizers on poor soils for increasing of yield (Bindraban et al., 2015). Considerable importance providing scientists study the impact of organic residues to increase soil fertility, that according to some studies have a positive effect (Bandick, Dick, 1999; Bhardwaj, 2014; Sánchez de Cima, Luik \& Reintam, 2015). However, the crop rotation factor is crucial in the development and application of a particular fertilizer system.

Transition to short crop rotation takes place under conditions of reforms in agriculture. Therefore, an important task of today is the development and implementation of high yielding crop rotations with a small set of crops which are in high demand in the market, correspond to the optimal structure of agriculture and do not spoil soil fertility (Yeshchenko, 2015; Boiko, Kovalenko \& Opara, 2014; (New Zealand Climate Chanqe Office NZCC, 2017). 
To increase in crop rotation of legum crops makes it possible to efficient use their by-products as organic fertilizers. It is proved that today soy is one of the main leguminous crops, which determines the reliable level of vegetable protein production. Plant breeders have created a new generation of short-season varieties adapted to Polissia conditions, so the soybeans have good prospects to increase their further production (Kaminskyi, 2015). Correct location in sunflower rotation is also of great importance. Different scholars have their own opinion as to the minimum allowable period for returning this culture to its previous location. The scientists and agriculturers are not ambivalent about this interval duration, and consequently they also have different opinion about maximum sunflower rotation. The overwhelming majority of scientists concerned with this problem believe that sunflower should return to its previous location no later than in 7-8 years. At the same time, some scientists have argued that this interval can be much shorter, given that modern hybrids and sunflower varieties have 100 percent carcinogenicity, and high resistance to lupus and disease (Khomiak \& Andriichenko, 2013).

The purpose of research is to determine the optimal fertilizer system for drained sod-podzolic soil for crops nutrient providing by replacing litter manure with local organic materials in combination with environmentally balanced doses of mineral fertilizers and for improving the productivity of short-term crop rotation and preserve the fertility of analyzed soil.

\section{MATERIALS AND METHODS}

The given research has been conducted at the experimental site of Institute for Agriculture of Polissia NAAS (IAP NAAS), located in Korosten district of Zhytomyr region (v. Grozyne), on drained by tile drainage sod-podzolic sandy loam with unilateral control of air and water regime. According to the reports of field research, Department of Agriculture and Land Reclamation of IAP NAAS by 2016 the soil on a research area is characterized by average humus level $(1.27 \%)$, total nitrogen $(0.063 \%)$, labile phosphorus (84), exchange potassium (101 mg/kg of soil), pHsol. (5.0), and hydrolytic acidity (2.25 mg-eq. per $100 \mathrm{~g}$ of soil). 
In crop rotation fertilizer system provides: control (without fertilizers); byproducts $(\mathrm{b} / \mathrm{p})$; recommended rate $\left(\mathrm{N}_{41} \mathrm{P}_{56} \mathrm{~K}_{64}+10\right.$ ton of manure); alternative $\left(\mathrm{N}_{41} \mathrm{P}_{56} \mathrm{~K}_{64}+\mathrm{b} / \mathrm{p}\right) ; 1.5$ times increased rate of mineral fertilizers $\left(\mathrm{N}_{62} \mathrm{P}_{86} \mathrm{~K}_{96}+\mathrm{b} / \mathrm{p}\right)$ (Table 1). Recommended fertilizer rates have been used for the crops: winter wheat $\mathrm{N}_{60} \mathrm{P}_{60} \mathrm{~K}_{60}$, sunflower $-\mathrm{N}_{60} \mathrm{P}_{60} \mathrm{~K}_{90}$, buckwheat $-\mathrm{N}_{45} \mathrm{P}_{45} \mathrm{~K}_{45}$, soybean $-\mathrm{P}_{60} \mathrm{~K}_{60}$. A plot of $28 \mathrm{~m}^{2}$ was selected for the research. The main way of soil cultivating is plowing. The varieties are soybean (Vorskla), winter wheat (Myronivska Yuvileina), sunflower (Yason), buckwheat (Gloria). The humus balance was performed according to the method of Lykov (1976).

\section{RESULTS AND DISCUSSION}

Results and discussions. One of the important conditions that influence the obtaining of constant crops on drained soils is optimal moisture of their soil during crop season.

Data from the reports of the Department of Agriculture and Land Reclamation of IAP NAAS on the observations conducted during 2016-2019 on the dynamics of soil moisture reserves point to increase of moisture deficit by the beginning of summer. If, at the beginning of spring field work, soil moisture levels were 150-180 $\mathrm{mm}$, then by mid-summer they reduced to a critical level. The lack of moisture under high air temperature condition led to groundwater level decrease to $2.5-3 \mathrm{~m}$.

On average, over the years of observations, the yield on fertilized plots by soybeans, winter wheat, sunflowers and buckwheat increased by $0.39 ; 1.20 ; 0.65$; $0.39 \mathrm{t}$ per 1 ha, depending on the fertilizer system (Table 1).

Table 1. Crop yield capacity (ton/ha) and rotation (ton of crop varieties) depending on fertilizer system (in average for 2016-2019)

\begin{tabular}{|l|c|c|c|c|c|}
\hline \multirow{2}{*}{ Fertilizer system } & \multicolumn{4}{|c|}{ Rotation crops } & $\begin{array}{c}\text { Yield of cr. var., ton per } \\
\text { 1 ha of crop rotation area }\end{array}$ \\
\cline { 2 - 6 } & soybean & winter wheat & sunflower & buckwheat & 2.11 \\
\hline Without fertilizers & 1.18 & 2.44 & 1.50 & 1.19 & 2.33 \\
\hline 2.0 ton b/p & 1.25 & 2.82 & 1.75 & 1.22 & 2.98 \\
\hline $\begin{array}{l}10 \text { ton of manure }+ \\
\mathrm{N}_{41} \mathrm{P}_{56} \mathrm{~K}_{64}\end{array}$ & 1.42 & 3.53 & 2.30 & 1.54 & \\
\hline
\end{tabular}




\begin{tabular}{|l|c|c|c|c|c|}
\hline 2.9 ton $\mathrm{b} / \mathrm{p}+\mathrm{N}_{41} \mathrm{P}_{56} \mathrm{~K}_{64}$ & 1.44 & 3.67 & 2.10 & 1.41 & 2.80 \\
\hline 3.3 ton $\mathrm{b} / \mathrm{p}+\mathrm{N}_{62} \mathrm{P}_{84} \mathrm{~K}_{96}$ & 1.64 & 4.02 & 2.40 & 1.61 & 3.20 \\
\hline $\mathrm{HIP}_{05}$, ton/ha & 0.12 & 0.32 & 0.18 & 0.14 & 0.28 \\
\hline
\end{tabular}

Note: $\mathrm{b} / \mathrm{p}$ is by-product; $\mathrm{cr}$. var. is crop varieties

Our studies have indicated the highest wheat yield capacity was observed on the raised background $\left(\mathrm{N}_{90} \mathrm{P}_{90} \mathrm{~K}_{90}\right)$ in combination with by-products. Under such conditions grain yield was 4.02 ton/ha.

Sunflower was least affected by the lack of moisture. During four years of research, seed yields were almost stable: from 1.32-1.65 ton/ha in control to 2.12 2.72 ton/ha under conditions of high dose of mineral fertilizers in combination with by-products from previous crops.

Using the recommended fertilizer doze $\left(\mathrm{N}_{60} \mathrm{P}_{60} \mathrm{~K}_{90}\right)$ in combination with winter wheat straw 2.1 ton/ha of seeds were obtained. A significant increase in productivity was admitted after applying $\mathrm{N}_{60} \mathrm{P}_{60} \mathrm{~K}_{90}$ fertilizer against 40 ton/ha of manure -2.3 ton/ha. That is, in terms of efficiency, manure had an advantage over by-products. The increased doze of fertilizer $\mathrm{N}_{90} \mathrm{P}_{90} \mathrm{~K}_{135}$ adding straw and the recommended fertilizer $\mathrm{N}_{60} \mathrm{P}_{60} \mathrm{~K}_{90}$ with manure, in terms of the influence on seed yield, were equivalent (increment within the least significant difference).

According to the data for crop yields from Table 1, the overall crop rotation productivity with a part of winter wheat and sunflower (25\% each) was relatively low. Under control, the yield of grain units per 1 ha of crop rotation area was 2.11 tons, in biological option it was $10.4 \%$ more. The highest yield was recorded as 3.20 tons of grain units applying $\mathrm{N}_{62} \mathrm{P}_{84} \mathrm{~K}_{96}+\mathrm{b} / \mathrm{p}$, which is $7.4 \%$ more than under using 10 tons of manure $+\mathrm{N}_{41} \mathrm{P}_{56} \mathrm{~K}_{64}$.

It is known that one of the most important soil protection functions of rotation and conditions of its consistently high efficiency, along with optimization of nutritive regime is the creation of a deficit-free balance of humus and nutrients. Therefore, one of the goals of our research was to study the conditions of soil fertility preservation 
using mineral fertilizers and the involvement of biological nitrogen of legumes and by-products into the cycle.

We have conducted design analysis of humus balance (Lykov, 1976; Zozulia et al., 1986) and it has revealed that in crop rotation under condition of unfertilized soil there is a sharp decrease in soil fertility - humus losses are $430 \mathrm{~kg} / \mathrm{ha}$ per year. The plowing of all by-products into the soil contributed to the deficit-free balance of humus, the accumulation amounted to very little $-40 \mathrm{~kg} / \mathrm{ha}$ (Table 2).

According to the results of scientific studies (Zozulia, 1986) it has been established that positive humus balance should be at the level of $300-800 \mathrm{~kg} / \mathrm{ha}$. This increase provides enhanced soil reproduction and fertility boosting.

In the context of the recommended doze of mineral fertilizers $\left(\mathrm{N}_{41} \mathrm{P}_{56} \mathrm{~K}_{64}\right)$ and 10 tons of manure per 1 ha of crop rotation area (straw was removed from the field), humus growth was $100 \mathrm{~kg} / \mathrm{ha}$. Substitution of manure for alternative sources of organic matter (by-products of crops, legumes and oilseeds) contributed to a more active accumulation of humus in the soil (210 kg/ha), which ensures simple reproduction of its fertility.

All by-products under conditions of higher NPK than normal contributed to the increase of biomass output and the inflow of plant residues. Consequently, the annual accumulation of humus increased to $350 \mathrm{~kg}$, which provides enhanced soil reproduction and fertility boosting.

Table 2. Balance of nutrients and humus in soil (0-20 cm layer) depending on crop rotation fertilizing system (in average for 2016-2019)

\begin{tabular}{|l|c|c|c|c|}
\hline \multirow{2}{*}{ Crop rotation fertilizing system } & \multicolumn{3}{|c|}{ Balance, kg per 1 ha of crop rotation area } \\
\cline { 2 - 5 } & humus & nitrogen & phosphorusy & potassium \\
\hline without fertilizers & -430 & -48 & -20 & -58 \\
\hline 2.0 ton of b/p & 40 & -28 & -16 & -11 \\
\hline 10 ton of manure $+\mathrm{N}_{41} \mathrm{P}_{56} \mathrm{~K}_{64}$ & 100 & 27 & 56 & 97 \\
\hline 2.9 ton of b/p $+\mathrm{N}_{41} \mathrm{P}_{56} \mathrm{~K}_{64}$ & 210 & 2 & 36 & 47 \\
\hline 3.3 ton of $\mathrm{b} / \mathrm{p}+\mathrm{N}_{62} \mathrm{P}_{84} \mathrm{~K}_{96}$ & 350 & 6 & 72 & 75 \\
\hline
\end{tabular}


Besides, the measure of soil fertility is a balance of the most important nutrients - nitrogen, phosphorus and potassium.

The quantity of nutrients carried out by the crops characterizes its economic yield, which in all cases is less than biological. This is because the part of nutrients contained in root residues is not taken into account when determining economic yield, since it remains in the soil as organic by-products.

We have only calculated the economic nitrogen balance, that is, the balance in the system of 'plant - fertilizer', taking into account the nitrogen fixation coefficients of legumes and not taking into account changes in the total nitrogen content in the soil, which is determined in the long-term observation cycle.

Besides nitrogen losses from crops, gaseous losses of nitrogen from mineral and organic fertilizers, as well as fluviraption beyond the soil profile by downstream waters have been taken into account. Biological nitrogen, which is fixed by legumes from the atmosphere, gains from organic and mineral fertilizers, rains and seeds have been determined as beneficial.

As a result, without mineral fertilizers, a negative nitrogen balance has been achieved: under control it amounts $48 \mathrm{~kg}$; in case of by-products - $28 \mathrm{~kg}$ per 1 ha of crop rotation area. The deficit-free balance is noted if by-products are used within the limits of the recommended and increased NPK dose. A positive nitrogen balance of over $27 \mathrm{~kg}$ per year is achieved when 10 tons of manure in combination with the recommended NPK dose are used as soil fertilizers. The balance intensity in this case is $122 \%$, which exceeds the regulatory requirements.

According to literary sources (Zozulia, 1986), in order to create an activepositive balance of nutrients and significantly increase the fertility of sod-podzolic soils, the soil of Polissia should correspond to the following correlation of nutrients: nitrogen - 105-110\%, phosphorus - 200-260\%, and potassium - $120-150 \%$.

As to phosphorus and potassium, their deficit under control is 20 and $58 \mathrm{~kg}$, respectively. The use of by-products has not totally compensated their loss for main products yield. Excess losses of phosphorus and potassium are compensated for mineral fertilizers, manure and by-products. Under the recommended NPK doze and 
straw, excess of phosphorus and potassium is 36 and $47 \mathrm{~kg}$ respectively, which in relation to the losses is 222 and $158 \%$, that is, close to the regulatory limits. And if 10 tons of manure is applied per 1 ha of crop rotation area, the intensity of phosphorus and potassium (as well as nitrogen) balance exceeds the regulatory limits (294 and $214 \%$ respectively). Excess balance of phosphorus and potassium is also observed when mineral fertilizer is 1.5 times increases its norm.

Increased levels of nutritional elements balance indicate nutrient imbalance. Therefore, in further studies, it is necessary to review the rates of mineral fertilizers in the direction of their reduction, provided the application of litter manure and high rates of phosphorus and potassium.

Conclusions. The determinants of crops productivity and fertility of drained sod-podzolic soils without water regime regulation are moisture supply during the growing season and optimization of nutritive regime. An alternative to manure is byproducts plowing, which, in the context of moderate fertilizer rates, does not significantly reduce crop productivity and provides a deficit-free balance of humus and nutrients. Research has shown that the most noticeable enhance of crop productivity was observed from a 1.5-times increase in the rate of mineral fertilizers $\left(\mathrm{N}_{62} \mathrm{P}_{86} \mathrm{~K}_{96}\right)$, which was combined with plowing of precursors by-products of $3.3 \mathrm{t} /$ ha. This fertilizer system also has provided a positive balance of nutrients and humus in short rotation, that is: for humus $350 \mathrm{~kg}$ per 1ha of crop rotation area, nitrogen, phosphorus and potassium respectively $-6,72,75 \mathrm{~kg}$ per 1 ha.

\section{REFERENCES}

Boiko P. I., Kovalenko N. P., \& Opara M. M. (2014). The effective reversible crop rotation in modern agriculture. Bulletin of Poltava State Agrarian Academy, No.3, 20-32. (in Ukrainian) https://doi.org/10.31210/visnyk2014.03.04

Bandick A. K., Dick R. P. (1999). Field management effects on soil enzyme activities. Soil biology and biochemistry, Vol. 31(11), 1471-1479. https://doi.org/10.1016/S0038-0717(99)00051-6

URL: https://www.sciencedirect.com/science/article/abs/pii/S0038071799000516 (Accessed: 13.04.2020). 
Bhardwaj D., Ansari M. W., Sahoo R. K., \& Tuteja N. (2014). Biofertilizers function as key player in sustainable agriculture by improving soil fertility, plant tolerance and crop productivity. Microbial cell factories, Vol. 13(1): 66. https://doi.org/10.1186/1475-2859-13-66.

URL: https://link.springer.com/article/10.1186/1475-2859-13-66 (Accessed: 15.04.2020).

Bindraban P. S., Dimkpa C., Nagarajan L., Roy A., \& Rabbinge R. (2015). Revisiting fertilisers and fertilisation strategies for improved nutrient uptake by plants. Biology and Fertility of Soils, Vol. 51(8), 897-911. https://doi.org/10.1007/s00374-015-1039-7

URL: https://link.springer.com/article/10.1007/s00374-015-1039-7

(Accessed: 15.04.2020).

Chen J. H. (2006). The combined use of chemical and organic fertilizers and/or biofertilizer for crop growth and soil fertility. International workshop on sustained management of the soil-rhizosphere system for efficient crop production and fertilizer use, Land Development Department, Bangkok, Thailand. Vol. 16, No. 20, $1-11$.

URL: http://citeseerx.ist.psu.edu/viewdoc/download?doi=10.1.1.474.2251\&rep=rep1\&type $=\operatorname{pdf}$ (Accessed: 15.04.2020).

Chen L., Li F., Li W., Ning Q., Li J., Zhang J., ... \& Zhang C. (2020). Organic amendment mitigates the negative impacts of mineral fertilization on bacterial communities in Shajiang black soil. Applied Soil Ecology, Vol. 150, 103457. https://doi.org/10.1016/j.apsoil.2019.103457

URL: https://www.sciencedirect.com/science/article/abs/pii/S0929139319307504 (Accessed: 14.04.2020).

Coastal Hazards and Climate Chanqe. A Guidance Manual for Local Govemment in New Zealand. (2017). NZCC (New Zealand Climate Chanqe Office). URL: https://www.mfe.govt.nz/publications/climate-change/coastal-hazards-andclimate-change-guidance-local-government. (Accessed: 23.02.2020).

Guo Z., Wan S., Hua K., Yin Y., Chu H., Wang D., \& Guo X. (2020). Fertilization regime has a greater effect on soil microbial community structure than 
crop rotation and growth stage in an agroecosystem. Applied Soil Ecology, Vol. 149, 103510. https://doi.org/10.1016/j.apsoil.2020.103510

URL: https://www.sciencedirect.com/science/article/abs/pii/S0929139319302896 (Accessed: 13.04.2020).

Kaminskyi V. F. (2015). Crop rotation as a basis for sustainable land use and food security in Ukraine. Collection of Scientific Reports of the National Science Center Institute of Agriculture NAAS, No. 2, 3-14. (in Ukrainian).

Khomiak P., Andriichenko L. (2013). Sunflower cultivation in short rotation. Propozitsiya, No. 4. 78-81. (in Ukrainian).

Lykov A.M. (1976). By the method of calculation of the soil humus balance in intensive agriculture. Scientific journal "Izvestiya of Timiryazev Agricultural Academy", No. 6. 24-28. (in Russian).

Pashkova M. (2019). Winter wheat productivity on drained sod-podzolic soils of Volyns Polissya depending on applying fertilizer systems and temperature conditions. Land Reclamation and Water Management, (1), 61-66. https://doi.org/10.31073/mivg201901-168

URL: http://mivg.iwpim.com.ua/index.php/mivg/article/view/168 (Accessed: 15.04.2020).

Sánchez de Cima D., Luik A., \& Reintam E. (2015). Organic farming and cover crops as an alternative to mineral fertilizers to improve soil physical properties. International agrophysics, Vol. 29(4), 405-412. https://doi.org/10.1515/intag-20150056 URL: http://agro.icm.edu.pl/agro/element/bwmeta1.element.agro-8dd85f681281-4a61-9600-02f1d654ced2/c/02_29-4-paper_405.pdf (Accessed: 15.04.2020).

Savchuk O. I., Melnychuk A. O., Drebot O. V., Kudryk A. P., Budnik I. P. (2018). The status and management of the reclaimed lands within Zhytomyr Polissya under climate change. Collection of Scientific Reports "Agroindustrial production of Polissya", Zhytomyr, 2018. No. 11. 12-16. (in Ukrainian).

Shah S. A., Mohammad W., Shah S. M., \& Shafi M. S. (2015). Effect of organic and chemical nitrogen fertilizers on grain yield and yield components of wheat and soil fertility. Journal of Crop Nutrition Science, Vol. 1(1), 63-74. URL: http://jens.iauahvaz.ac.ir/article_522616.html (Accessed: 14.04.2020). 
Yeshchenko V. O. (2015). The role of crop rotation in modern farming. Farming, No. 1, 23-27. (in Ukrainian).

Zozulia A. K., Dudchenko I. V., Kotvytskyi V. B., Zinchuk P. I., Biruk I. Z. (1986). Recommendations to determine the balance of humus and nutrients in the farms of Volyn region. Lutsk. 48. (in Ukrainian).

О. І. Савчук, А. О. Мельничук, О В. Дребот, А. П. Кудрик, О. В. Зубова Вплив системи удобрення на родючість осушуваного дерново-підзолистого грунту в короткоротаційній сівозміні

Анотація. Актуальність досліджень полягає в ефективному використанні осушених земель. Мета. Визначити оптимальну систему удобрення осушуваного дерново-підзолистого грунту та вивчити іiі вплив на його родючість за умов впровадження короткоротаційної сівозміни: соя - пшениця озима - соняшник - гречка. Методи. Дослідження проводились в польових умовах та виконані в межах закладеного трьохрічного досліду. Урожайність підраховано методом зважування. Баланс гумусу в грунті виконано за методикою А. М. Ликова. Результати. Упродовж вегетаційних періодів 20162019 років найменше реагував на грунтово-повітряну посуху соняшник, який на фоні рекомендованої норми $\mathrm{N}_{60} \mathrm{P}_{60} \mathrm{~K}_{90}$ сумісно 340 т/га підстилкового гною та підвищеної норми $\mathrm{N}_{90} \mathrm{P}_{90} \mathrm{~K}_{135} 3$ 4,0 т побічної продукції попередника забезпечив урожайність насіння на рівні 2,3 і 2,4 т/га відповідно. Максимальний збір продукції 31 га сівозмінної площі відмічений на підвищеному фоні (N62P84K96 + 3,3 т побічної продукції) - 3,20 т зернових одиниць. Висновки. Альтернативна система удобрення (заміна 10 т гною на 1 га ріллі побічною продукцією в кількості 3,3 т на фоні мінеральних добрив) забезпечила позитивний баланс поживних речовин та гумусу в короткоротаційній сівозміні. Перспективи. В подальших наукових дослідженнях передбачається зниження кількості внесення фосфорних та калійних добрив за умови заорювання побічної продукції всіх культур сівозміни.

Ключові слова: осушені грунти, продуктивність, родючість грунту.

О. И. Савчук, А. А. Мельничук, О В. Дребот, А. П. Кудрик, Е. В. Зубова 


\section{Влияние системы удобрения на плодородие осушенных дерново-}

подзолистых почв при короткоротационном севообороте

\section{Аннотация.}

Актуальность исследований заключается в эффективном использовании осушенных земель в условиях изменений климата. Цель. Определить оптимизированную систему удобрения и изучить ее влияние на плодородие дерново-подзолистой почвы в короткоротационном севообороте: соя пшеница озимая - подсолнечник - гречиха. Методы. Исследования проводились в полевых условиях и были выполнены в пределах заложенного трехлетнего опыта. Урожайность определена методом взвешивания. Баланс гумуса в почве был рассчитан по методике А. Н. Лыкова. Результаты. В течение вегетационных периодов 2016-2019 гг. меньше реагировал на почвенновоздушную засуху подсолнечник, который в фоне рекомендованной нормы $\mathrm{N}_{60} \mathrm{P}_{60} \mathrm{~K}_{90}$ совместно с 40 т/га подстилочного навоза и повышенной нормы $\mathrm{N}_{90} \mathrm{P}_{90} \mathrm{~K}_{135}$ с $\quad 4,0$ т побочной продукции предшественника обеспечил урожайность семян на уровне 2,3 и 2,4 т/га соответственно. Максимальный сбор продукции с 1 га площади севооборота отмечен на повышенном фоне $\left(\mathrm{N}_{62} \mathrm{P}_{84} \mathrm{~K}_{96}+3,3\right.$ т побочной продукции) - 3,20 т зерновых единиц. Выводы. Альтернативная система удобрения (замена 10 т навоза на 1 га пашни побочной продукцией в количестве 3,3 т на фоне минеральных удобрений) обеспечила положительный баланс питательных веществ и гумуса в короткоротационном севообороте. Перспективы. В дальнейших научных исследованиях предполагается снижение количества внесения фосфорных и калийных удобрений при запахивании побочной продукции всех культур севооборота.

Ключевые слова: осушенные почвы, продуктивность, плодородие почвы. 